\title{
Uygur dönemi Budist Sūtralarda yer alan ançulayu ärür mänì äşidmişim ifadesi üzerine
}

Hasan İSí1

APA: İsi, H. (2020). Uygur dönemi Budist Sūtralarda yer alan ançulayu ärür mänì äşidmişim ifadesi üzerine. RumeliDE Dil ve Edebiyat Araşttrmaları Dergisi, (19), 78-88. DOI: $10.29000 /$ rumelide.752136.

\section{$\ddot{\mathbf{O} z}$}

Eski Uygur Türkçesi, özellikle Uygur rahiplerinin Budizm ve Manihaizm temelli öğretiler çerçevesinde geliştirdikleri dinî terminolojinin somut örneklerinin verildiği dönem olma özelliğini taşımaktadır. Türk dilinin sistematik dinî terminolojisinin ilk örneklerinin verildiği bu dönem içerisinde yer alan çoğu metnin kaynak ya da aracı diller vasıtasıyla Eski Uygur Türkçesine aktarılması, ilgili öğretinin anlaşılması noktasında özellikle Budist Uygur rahiplerini hem Türkçe bilincine hem de ilgili öğretinin orijinalliğine sadık kalma güdüsü doğrultusunda hareket etmeye mecbur kılmıştır. Budist Uygur rahiplerinin öncülük ettiği tercüme faaliyetleri çerçevesinde başlayan dilcilik hareketleri, başlangıçta ilgili öğretilerin halka anlayacağı dille anlatılma arzusundan ileri gelse de zamanla benimsenen Türkçeleştirme yöntemleri ile dil bilincinin geliştiği görülmektedir. Bu Türkçeleştirme yöntemlerinden biri de, birebir çeviri yaparak ilgili öğretinin kaynak dildeki karşılıklarını Türkçe sözcük ve eklerle oluşturmaktır. Bu doğrultuda, Çince ve Tibetçe gibi kaynak ya da Soğdca ve Toharca gibi aracı diller vasıtasıyla Eski Uygur Türkçesine aktarılan metinlerde yer alan dinî kavramlar, özellikle Budist Uygur rahiplerinin uyguladıkları dil bilinci doğrultusunda Türkçeleştirilmeye çalışılmıştır. Bu yaklaşıma uygun Türkçeleştirme ürünlerinden biri de, Budist sūtralar içerisinde başlangıç sözü niteliğinde olan Skr. evam mayā șrutam ifadesinin birebir tercümenin ürünü olarak Eski Uygur Türkçesine ançulayu ärür mänin äşidmişim şeklinde aktarımının yapılmasıdır. Kaynak dilde "Şöyledir duyduğum, şöyle işittim!” anlamlarına gelen bu ifade, Eski Uygur Türkçesine ait metinlerde de bu anlam eksenini koruyarak şeklen Skr. evam mayā śrutam ifadesine benzer yönde söz dizilimine sahiptir. Bu yazl, Skr. evam mayā șrutam ifadesinin Eski Uygur Türkçesi metinlerindeki karşılığı olan ançulayu ärür mänī äşidmişim terimine yönelik dinsel ve dilsel değerlendirmelerden oluşmaktadır. Bu doğrultuda, ilgili kavramın dinsel yönü, Mahāyāna ve Tantracı gelenek içerisinde incelenerek ifadenin sahip olduğu dinî değer yönünde, kavramın Eski Uygur Türkçesi metinlerindeki görünümü yapısal olarak gösterilmeye çalışılmıştır.

Anahtar kelimeler: Eski Uygur Türkçesi, dinî terminoloji, Sūtralar, evaṃ mayā șrutam, "Duyduğum şöyledir!"

\section{On the expression ançulayu ärür mäniy äşidmişim in the Uyghur period Buddhist Sūtras}

\author{
Abstract \\ Old Uyghur Turkic has the feature of being the period when concrete examples of religious \\ terminology developed by Uyghur priests especially within the framework of Buddhism and \\ Manichaism based teachings. Translating most of the texts in this period, in which the first examples


of the systematic religious terminology of the Turkic language are given, to the Old Uyghur Turkic through source or intermediate languages, compelled the Buddhist Uyghur priests to act in accordance with both the Turkic consciousness and the authenticity of the teaching concerned. Although the linguistic movements that started within the framework of the translation activities led by the Buddhist Uyghur priests originated from the desire to be told in the language that the relevant teachings will understand to the public, it is seen that language consciousness has developed with the Turkishization methods adopted over time. One of these methods of Turkishization is to make the translations of the relevant teaching in the source language with Turkic words and suffixes by making one-to-one translations. Accordingly, the religious terms included in the texts that were transferred to Old Uyghur Turkic through such as sources languages Chinese and Tibetan or intermediary languages such as Sogdian and Toharian, were tried to be translated in line with the language awareness applied by Buddhist Uyghur priests. One of the Turkishization products suitable for this approach is Skr. evam mayā șrutam is the translation of Old Uyghur Turkic ançulayu ärür mänī äşidmişim as a product of one-to-one translation. In the source language, the meaning of "Thus have I heard" this expression, Old Uyghur Turkic texts in this meaning by preserving Skr. evam mayā srutam also has a syntax similar to the expression. This article consists of religious and linguistic evaluations for the term in Old Uyghur Turkic texts. ançulayu ärür mänin äşidmişim, which is the equivalent of Skr. evam mayā srutam. In this direction, the religious aspect of the related term, Mahāyāna and Tantra, have been studied in the tradition, and the concept of the concept in the Old Uyghur Turkic texts has been tried to be shown structurally in the direction of the religious value of the expression.

Keywords: Old Uyghur Turkic, religious terminology, Sūtras, evam mayā șrutam, "Thus have I heard"

\section{Giriş}

Türk dilinin dinî söz varlığının sistematik olarak ilk ürünlerinin verildiği dönem olarak da bilinen Eski Uygur Türkçesi, gelişkin ve işlenmiş bir dil olma özelliği taşımaktadır. 9. yüzyıldan 14. yüzyıla kadar ki süreci kapsayan bu dönemde, temasa girilen halklarla yaşanan kültürel ve ticari gelişmeler sonucu yeni dinler benimsenmiş, bu inanç kültürü doğrultusunda Uygur edebiyatının geliştiği görülmüştür. Budizm ve Manihaizm öğretilerini aktarma kaygısı taşıyan çevirmenlerin ortaya koyduğu ve sonradan özellikle Budist Uygur rahiplerinin üstlendikleri görevle dinî öğretileri halka ulaştırma amacı, çeviri bir edebiyatın doğuşunu sağlayarak çeşitli metinler aracılığıyla somut ürünlerin verilmesini sağlamıştır. Budizm ve Manihaizm temelinde Soğd ve Tohar tüccarlarının öncülük ettiği dinî gelişimi bu halklarla temas içerisinde kalarak tecrübe eden Uygurlar, aldıkları dinî terbiyeyi zamanla olgunlaştırarak özellikle Budist Uygur rahipleri öncülüğünde Türk Budizmini ortaya koymuşlardır. Budist Uygur rahiplerinin oluşturdukları tercüme heyetlerinin ilgili öğretiyi halka anlayacağı dille anlatma ve kavratma çabası, Türk diline yönelik filolojik çalışmaların başlangıcını da teşkil etmektedir. Bu doğrultuda, başta Buda öğretisi olmak üzere çeşitli inanç kültürlerine yönelik terimleri ya da kavramları orijinaline bağlı kalmak şartıyla birebir tercüme ile Türkçeye aktaran Uygur rahiplerinin geliştirmiş oldukları bu sistem, Türk dilinin dinî terminolojisinin oluşumuna katkıda bulunmuştur. Budist terminoloji içerisinde genellikle Budist sūtraların başlangıç formeli olarak kullanılan Skr. evaṃ mayā șrutam "Şöyle işittim!" ifadesi, Eski Uygur Türkçesi metinlerinde ançulayu ärür mänī äşidmişim terimine karşllı gelmektedir. Bu çalışmada, Budist Uygur rahiplerinin yaptığı birebir çevirinin ürünü olan ançulayu ärür mänī äşidmişim ifadesi ele alınarak ilgili terimin sahip olduğu dinsel değerle beraber kavramın çeviri kaynaklı gösterdiği söz dizimsel görünüm aktarılmaya çalışılmıştır. 


\section{Tanıklar}

Eski Uygur Türkçesine ait metinlerde Skr. evaṃ mayā șrutam ifadesine karşıllk gelen ançulayu ärür mänī äşidmişim "Duyduğum şöyledir!” ifadesinin geçtiği metinlere bakıldı̆̆ında, ilgili kavramın Mahāyāna mezhebine ait sūtralardan Säkiz Yükmäk’te yer aldığı devamında tanıklanan diğer örneklerin ise Vajrayāna ${ }^{2}$ mezhebi içerisindeki Tantrik Budizm'e dayalı anlatılarda kullanım bulduğu görülmektedir. Bu kavramın ifade ettiği dinsel ve dilsel değeri detaylı bir şekilde göstermeden önce, bu terimin genellikle Budist sūtraların giriş bölümünü oluşturduğunu ve devamında anlatılacak hikâyeye geçişi sağlayacak nitelikte geçerlik ve doğrulama özelliğine sahip olduğunu belirtmekte fayda vardır.

Säkiz Yükmäk 05-09: ançulayu ärürr mäniy äşidmişim: ymä bir üdün ulug ulug tükäl bilgä biliglig täyri täyrisi burhan vayşalı atlıg nomlug törölüg balıkta, key alkıg orduda, ontın sınarkı burhanlar uluşıntın kälmiş ärüş üküş bodis(a)t(a)vlar bo virtaki tört törlüg terin kuvrağı birlä yarlıkayur (Bang vd. 1934: 104).

"Şöyle işittim: Bir kez daha, mükemmel bilgelikle donatılmış tanrılar tanrısı Buda, Vais̄ālī denilen kendi sarayının olduğu şehirde, on kardinal yönden gelen Bodisattvalar ile öğretiyi tartışıyordu.” (Bang vd. 1934: 105).

Sitātapatrādhāraṇi /o7-10: ançulayu ärür mänị äşidmişim: ymä bir üdün ațı kötrülmiş strayastriş t(ä)yri yerintä sudaramşalta t(ä)yri-lärn[i]y yıgılgu[l]uk-ın (Kılıç Cengiz 2018: 54-55).

"Şu şekildedir ki işittim: Yine bir keresinde adı yüceltilmiş (Bhagavat), Trayastrimssāḥ (adlı) tanrı yerinde, Sudharma-șālā'da, tanrların meclisini..." (Kılıç Cengiz 2018: 218).

Ușṇiṣa Vijayā Dhāraṇī Sūtra/o4-o6: ançulayu ärür mäniy äşidmişim: ymä bir üdün atı kötrülmiş strayastriş t(ä)pri yerintä sudaramşal atl(1)g t(ä)prilärnin yıġılġuluk ... (İsi 2019: 143).

"Duyduğum şöyleydi: Yine bir gün adı yüceltilmiş tanrıların olduğu Trayastrimşat ülkesinde Suddharma-śala adlı korulukta...” (İsi 2019: 188).

ançulayu ärür mäniy äşidtüküm bar ärti: bir üdün bo üç qat yertinçü yer suvnuy umugiı ınaġı atı kötrülmiş ayaġka tägimlig tükäl bilgä t(ä)yri t(ä)yrisi burhan... (Kitsudo 2017: 35, 36).

“Öylece duyduğum (bir şey) vardı. Yine bir gün bu üç kat yer, su ve dünya'nın umudu olan adı yüceltilmiş saygıya değer tüm hikmetlere sahip tanrılar tanrısı Buda...”

Eski Uygur Türkçe dönemine ait sūtralarda, bu ifadenin tespit edildiği metin sayısı dörttür. Dört metinde de ifadenin giriş sözü niteliğinde anlatılacak öyküye tanık olunduğunu gösterme durumu söz konusudur. Dört metinde de ilgili ifadeden sonra Buda ve Buda topluluğunun yer aldığı cemaat hakkında tasvirler yapıldığı, özellikle Buda’ya yönelik sıfatların sıralandığı görülmektedir. Bu yönüyle, ançulayu ärür mänin äşidmişim "Duyduğum şöyledir!" <Skr. evam mayā șrutam ifadesi, Buda öğretilerinin yer aldığı sūtra türünün giriş formeli olarak Türkçeleştirilmiş dinî kavramlardan biri olma özelliğini taşımaktadır.

\footnotetext{
2 Vacrayāna olarak da bilinen bu mezhep, Kuzey Hindistan'a ve Tantrik Budizme ait bir okuldur. Temelde, yaklaşık olarak 7. yüzylda yazılmış olan Tantra metinlerine dayanır. Bu okul, kökende Mahāyāna yolunu izlese de birçok yeni tekniğe sahiptir. Ritüeller, ellerle yapılan simgesel hareketler (müdralar), mandalalar, dualar bu okulun temel özelliklerini oluşturur (Kaya 2017: 205, 206).
} 


\section{2. ançulayu ärür mänì äşidmişim ( $<$ Skr. evam mayā șrutam) ifadesi üzerine kavramsal değerlendirmeler}

Çalışmanın bu bölümünde, ilk kez Eski Uygur Türkçesi metinlerinde tanıklanan ançulayu ärür mänī äşidmişim “Duyduğum şöyledir!” ifadesi, sahip olduğu dinsel değerle beraber oluşum yönü bakımından Türk dilinin cümle yapısı dışında duran özelliklere sahip olması ile iki ayrı alt başlık içerisinde ele alınarak ilgili terimin taşıdığı kavramsal değerler gösterilmeye çalışılacaktır.

\section{1. Budist düşünce sisteminde Skr. evaṃ mayā șrutam ifadesi}

Eski Uygur Türkçesine ait metinlerde ançulayu ärür mänī äşidmiş̧im “Duyduğum şöyledir!” şeklinde görülen bu ifadenin Budist halkların dilinde karşılık bulduğu görünüm şu şekildedir:

Uyg. ançulayu ärür mänī äşidmişim=Skr. evam mayā șrutam (ekasmin samaye) $=$ Çin. 如是我聞 "rúshiwwǒ wén" =Jap. nyoze-gamon= Päli evim me sutam (ekam samayam)=İng. Thus have I heard "Duyduğum şöyledir, şöyle işittim!”.

Budizm'e dayalı öğretilerin benimsendiği kültürel coğrafyalarda özellikle Eski Uygur Türkçesinde ançulayu ärür mäniฤ äşidmişim şeklinde karşllık bulan bu ifadenin Budizm'le temasa geçmiş ve bu öğretiyi dinî yaşamın merkezine yerleştirmiş halkların dillerinde de karşılık bulduğu yukarıda verilen karşılaştırmada görülmektedir. Budizm'e yönelik modern çalışmalarda Batıda "Thus have I heard" ifadesine karşıllı gelen bu kavram, Skr. evam mayā șrutam (ekasmin samaye) ifadesine gitmektedir. Budizm'e dayalı anlatılar içerisinde doğrudan Buda anlayışını yansıtan sūtralar aracılığıyla görülen bu ifade, çeşitli kültürlerin dinî ve edebi yaşamlarında kullanılan Budist formelleden biri olma özelliği taşımaktadır.

\section{Mahāyāna mezhebi'nde evaṃ mayā șrutam}

Mahāyāna mezhebine ait sūtraların başlangıç bölümünde Buda öğretisine dayalı vaazlar verilmeden önce, Buda ve Bodisattvaların yer aldığı mekânlar hakkında bilgiler verilmektedir. İlgili tanıtım bölümlerinden sonra, usta kişi öğrencilere öyküler anlatarak onlara problemlerin nasıl çözüleceği hakkında sorular sormaktadır. Bu sohbetin en ünlü sembolleri, Ānanda, S̄āriputra, Subhūti ve Mañjuşri'dir. Bu doğrultuda bu tür eserler, "Bhagavan bir vakit, bir zamanlar...” ifadesine karşılık gelen Skr. evam mayā șrutam ekasmin samaye bhagavān giriş cümlesiyle başlamaktadır (Khiewngamdee 2017: 73). Budist geleneğe göre, sūtraların girişinde yer alan bu ifade, Buda’nın sadık keşişi Ānanda'nın ilk konseydeki öğretileri hafızasından okuduğunu hatırlatan bir kavramdır. Ānanda ile ilişkilendirilen ve doğrudan sūtraların girişinde yer alan bu ifade, bir metnin sūtra statüsüne sahip olduğunu ve belirli bir tarihsel yönde bağlantısı olduğunu gösteren tescil ifadesi özelliğini taşımaktadır (Osto 2004: 114).

Buda öğretilerini yansıtan metinlerde ana hikâyeye geçiş özelliği de taşıyan Skr. evam mayā shrutam ekasmin samaye ifadesinin Budizm içerisinde ortaya çıkışına bakıldığında, bu kavramın Buda'nın müridi olan Ānanda ile gerçekleştirdiği dinî uygulamalara dayandı̆̆ı bilinmektedir. Budist gelenek içerisinde, Buda'nın derlenen ilk sözlerinde, Ānanda'nın “Duyduğum şey böyledir” ifadesinden yararlanılmıştır ve Buda'nın verdiği vaazları duyan kişinin aklına gelen öğretiyi anlatırken bu sözle vaaza başlaması zamanla Budistlerce bir ritüel haline gelmiştir (Gakkai, Dictionary of Buddhism, This is what I heard maddesi); (Kaya 2017: 82, 182). 
Buda ve müridi Ānanda arasında geçen konuşmalardan oluşan ve zamanla Ānanda'nın tanıklığında anlatılagelen öğreti ifadelerine geçişin ve bu öğretilere ait geçerlik ve doğruluğun delili olan Skr. evam mayā șrutam ifadesi, Buda'nın öğretileri koruması adına görevlendirdiği ve başlarında Bhadrapala'nın olduğu beş yüz takipçiye olan inancından da ileri gelmektedir (Harrison 1979: xxı11).

Buda'nın ölümünden 3 ay sonra, 500 saygın rahip ilk konsey olarak da bilinen Rajagriha şehrinde bir araya geldi. Rajagriha, Eski Hindistan'da Magadha'nın içerisinde Kosala, Vansa ve Avanti gibi dört büyük krallıktan biriydi. Bu konseyin amacı, Buda’nın öğretilerini tanımlamak için Budist Kanonlar oluşturmaktı (Kozak 2017: 113). Geleneksel Budizm içerisinde Mahāyāna sūtraların özgünlügüu, bu mezhebin iniş çıkışları göz önüne alındığında, tartışmalı bir durum sergilemektedir. Kutsal metinler, Mahāyāna hareketinden önce dört kez derlense de yeni sūtralar, Mahāyāna mezhebinin kuruluşuyla bir kez daha yazıya geçirilmiştir. Mahāyāna sūtraların başlangıcında, yer ve özel adlar, Skr. evam mayā śrutam ifadesi ile söylenmiştir. Bu giriş, bazı yetkileri talep etmek için sūtra düzeni içerisinde kullanılsa da sūtralar, kendi içerisinde birçok sorun barındırmaktadır (Kim 2003: 146). Bu sorun zamanla, Theravāda ve Mahāyānacılar arasında tartışmalar başlatmıştır. Budistler3 Mahāyānacıları Buda öğretisinden ziyade, Mārā4'nın öğretilerini Buda öğretisi gibi sūtralara yerleştirmelerine itiraz etmiştir. Theravāda mezhebinde olanlar ise, Rajagriha Toplantısı'nda Buda'nın sözlerini, Buda öğretilerinin tüm ögelerini içeren Pāli Tripitakaları içinde toplandığını belirterek tarihsel Buda'nın öğretilerinin özgün olduğuna inanmaktadır (2003: 147).

Çoğu Budist sūtranın tanıtıcı ifadesi olan Skr. evam mayā șrutam ifadesi, kavram, zaman, yer, usta ve dinleyici gibi dört duruma işaret etmektedir. Bu dört şeyin bir araya gelmesi, Budistlere kutsal çağlarda gerçekleşmiş hayırlı bir durumu anımsatmaktadır. Bu kutsal çă̆, Buda'nın tüm canlıları kurtarma ve kurtuluşa erdirme adına verdiği söz (pranidhana) ya da yüce davranışlarla ulaştı̆̆ı (Bodhisattva-carya) seviyeye kadar geçen süreyi ifade etmektedir. Tarihsel ve dinsel derinlik açısından bu kavram, dinleyiciler açısından "bir zamanlar" ifadesi ile sonsuzluğu çağrıştırmaktadır (Miyamoto 1959: 119).

$\mathrm{Bu}$ formül, dile getirilen sözün Buda sözü olarak bilinen buddhavacana teriminin doğruluğunu göstermektedir. Lotus Sūtra ve Tantra gibi Mahāyāna Sūtralarda bu ifade, Ānanda ile ilişkili olsa da bu kavram, Buda tarafından vaaz edildiği söylenilen öğretinin Ānanda tarafından duyulmadığını, ilgili öğretinin Bodisattva Vajrapāṇi gibi başka kimseler tarafindan duyulduğu anlamına da gelmektedir (Dibeltulo Concu 2017: 496).

\section{Tantracı gelenek’te evam mayā śrutam}

Tibet Budizmi'ne dayalı gelişen Tantracılık’ta Skr. evam mayā śrutam ifadesi, geleneksel Budizm'de olduğu gibi, bu geleneğe ait Budist sūtralarda da giriş cümlesi olarak Pāli Kanonlarında yer alan evam me suttam ifadesine karşıllk gelmektedir (Dan O'Huiginn 2005: 21).

Tüm Budist Tantralar, tantrik sistemin dil analizini uygulayarak sadece bazı kişilerin bildiği gizli bilgiler içermektedir. (Farrow ve Menon 2001: xx, xxi). Tantralarda giriş cümlelerinde bu ifadenin kullanılmasına gerekçe oluşturan temel durum, Bhagavan'ın gerçek durumunu, yoga açısından tanımlamaktır. Bu ifade, yoga vücudu içerisinde yer alan Buda alanları ile konumlu akıl, konuşma ve

3 Hindistan'daki çoğu Budist gibi günümüz bilginleri de Buda’nın ölümünden sonra, Mahāyāna sūtraların uzun bir süre içerisinde derlendiğini belirterek onların verdiği Buda konuşmalarının tarihsel olmadığını düşünmektedir (McMahan 2002: 100).

$4 \quad$ Budist mitolojide kötü ruhun kisileștirilmiş halidir. Efsaneye göre, Bodhi ağacının altında aydınlanmakta olan Nuda’ya defalarca saldırır fakat onu aydınlanmaktan caydıramaz ve onun Buda oluşunu engelleyemez. Budist mitolojide çok sayıda Mārā vardır. Bunların amacı, insanları sersemletip cahil kalmalarını sağlamaktır (Kaya 2017: 132). 
zihnin merkezini gösterir. Evaṃ 5 mayā srutam ifadesi, tantrik dil sistemi aracılı̆̆ıyla, aydınlanma durumuna ve kullanılan yöntemin ayrıntılı oluşuna işaret etmektedir. Evam mayā ifadesi, öğretiye uygun şekilde Bhagavan'ın durumunun bilindiğini göstermektedir. Tantrik dil sistemi yoluyla, evam ifadesi, akıl ve metodun özünü temelde gösteren durumları temsil edebilme demektir. Mayā ifadesi ise bu birliğin etkin durumunu sembolize etmek için söylenmektedir. Bu doğrultuda evam mayā ifadesi, bilgelik ve metotların başarı ile karıştırılması demektir. Bu iki bileşenin birliği, akıl ve metot gibi iki kutsal varlığın birliği demektedir. Sürecin mükemmelce etkinleştirilmesi ya da doğuştan gelen doğanın farkına varılması olan evam yöntemi, mayā ifadesi ile kullanılmaktadır. Budalık sürecine ilerleme durumunda uygulanan metot ${ }^{6}$, evam mayā ifadesinin tantrik dildeki kullanımı yoluyla gösterilmektedir. Bu sürece yönelik olarak șrutam ifadesi, ilgili öğretinin sahip olduğu detayları ifade etmektedir. Bu doğrultuda "Şöyle işittim!" ifadesi, doğuştan gelen aydınlanmış bilinç durumu demektir (Farrow ve Menon 2001: xxiii).

Tantracı geleneğe mensup kişi, öncelikle Skr. evam mayā șrutam ifadesi ile ilgili öğreti hakkında söyleyeceği beyanı "öğretmenimin inançlılığına tanık ederek ilk bölümü tamamladım, yer ve zamanı gösterdim, kendimi bu öğretide yetkilendirdim.” şeklinde ifade ederek kendi yönteminden bahsetmektedir. Anlatıcının izlediği yolu gösterdiği bu kavram, Skr. evam mayā șrutam terimi içerisinde yer alan Skr. evam "şöyle" ifadesidir. Mayā ifadesi, duyulan ifadenin içerisinde yer alan çelişkinin çürütülmesi demektedir. İngilizce çevirilerde "Thus I have heard" 7 ifadesi içerisinde yer alan heard yani șrutam ifadesi ise, dinleme bilgisiyle elde edilmiş şey olarak "bir vakit, bir zaman" ya da "başka bir zaman” anlamlarına gelerek özellikle Tantralarda birey için anlaşılabilir olan birçok şeyin duyulduğunu göstermektedir (Hartzell 2012: 101).

\subsection{Sentaktik ödünçleme örneği olarak: ançulayu ärür mäniฤ äşidmişim ifadesi}

Manihaizm ve Budizm gibi evrensel dinler, geleneksel Türk dinine yabancı inanç sistemleri olarak eski Türk dininde bulunmayan yeni dinî kavramlar ve terimleri, Türk düşünce sistemi içerisine yerleştirerek hem toplumsal hem de dilsel açından değişimlere sebep olmuştur. Bu uyarlama ürünlerinden biri de, Skr. evam mayā șrutạ̣ şeklinde gösterilen “Duyduğum şöyledir!” ya da “Şöyle işittim!” ifadesinin Eski Uygur Türkçesine ait metinlerde ançulayu ärür mänī äşidmişim terimine karşllık gelmesidir. Tercüme faaliyeti ile Türk diline kazandırılan bu ifade, sahip olduğu söz dizimsel görünümle dikkat çekmektedir.

\footnotetext{
$5 \quad$ Skr. evam ifadesi, "böyle" demektir. Her sūtranın başında Buda tarafından söylenen sözler için evam mayā śrutam ifadesi, yer almaktadır. Vajrayana Budizminde evam ifadesi, kadın ve erkeğin birlikteliğini temsil etmektedir. Evam sözcüğü, Tibet Budizmi'nin en eski okulu olan Nyingma geleneği ve Kagyü okulunun gurusu Trungpa için kullanılmaktadır (Ed. Gimian 2004: xxix).

$6 \quad$ Tantrik Budizm ya da Tantracı gelenek içerisinde, metot denilen teknikler, Budalık yolunda önem arz etmektedir. Tantrik Budizm, Budalığa hızlıca ulaşmak için sayısız özel teknik ve Budist uygulamaların son noktasını oluşturduğu için genellikle "Metot aracı" olarak adlandırılır (Powers 2007: 250). Tantrik uygulamalar, ritüel çağrıştırmaya odaklanmaktadır. Özellikle mantraların, görsellerin ve tanrıların kullanımı yoluyla, bazı uyanmalar gerçekleşmektedir. Böyle metotlar, aslında tam olarak Mahāyānanın mutlu olma amacını taşımaktadır. Bunlar, derin dinî tecrübe ile Budalığa uzun Bodisattva yolundan daha kısa ve hızlı şekilde ulaşma amacından ileri gelmektedir (Harvey 2013: 180).

Skr. evam mayā șrutam ve Pāli dilinde evam me sutam şeklinde karşılık bulan "Thus have I heard" ifadesi, sūtralar içerisinde yer alan söylemleri tanıtan bir formüldür. Bu açllı̧̧ formülü genellikle, söylemin olduğu özel bir yer ve durumu göstermektedir. Nidāna olarak da bilinen önsözle öğreti anlatılmaktadır (Keown 2004: 89). Mahāyāna sūtralarda yaygın ifadelerden biri olan evam mayā șrutam yani "Böyle işittim!” ifadesi, erken dönemlerde sözlü olarak Buda’nın öğretilerinin yayılmasına olan inancı destekleyen bir kavramdır. "Thus have I heard” içerisinde yer alan "benim=I" ifadesi, tartışmalı kavramlardan biridir. Theravāda Budistleri, sonradan Sutta-pitaka içerisinde derlenen Buda öğretilerinin tümünü hatırlayan ve ezberde tutan kişinin Ānanda olduklarına inanmaktadır. Bu kavram, zamanla işiteni bilinmez kılarak, inanç niteliğine sahip sūtraların herkes tarafından duyulabileceğini ve anlaşılabileceğini göstermektedir (Jayadi 2019: 44) Ayrıca, "Thus I have heard" olarak temsil edilen bu ifade, Batılı araştırmacılarca gösterilen beş sembolik anlama sahiptir. 1. Thus "şöyle" ifadesi, öğreti demektedir.2. I "ben” ifadesi, öğrenciyi karşlamaktadır. 3-4. "have heard" ifadesi, özel bir yer ve zamanda dharma’yı bildirme demektir. 5. "Thus have I heard" ifadesi bu yönüyle, özel bir yer ve zamanda öğrencinin öğretiyi öğretmeninden duyduğunu bildirir. Bu beş durum olmadan Skr. evam mayā șrutam ifadesi söylenemez. (Ed. Gimian 2004: 484).
} 
Görünüm açısından Hint Avrupa dillerine özgü, yüklemin sonda değil de ortada olduğu bu ifade, devrik tümce özelliği taşımaktadır. Bu ifade özelinde Eski Uygur Türkçesinin söz dizimine yönelik görüşlerde bulunan isimlerin değerlendirmelerine bakıldığında, Hacer Tokyürek, Eski Uygur Türkçesinin dinî, siyasi, ticari, sosyal ve kültürel nedenlerden yabancı dillerin özellikle de Soğdca ve Toharca gibi dillerden etkilendiğinden bahsederek çeviriye dayalı gelişen etkilerin yalnızca söz varlığına değil, gramatik olarak da etkilere sahip olduğunu belirtmektedir (2013: 551). Bu yönüyle, Uygur dönemi yabancı etkileri yansıtan cümle dizilimlerini Budist Uygur rahipleri ${ }^{8}$ nin gerçekleştirmiş oldukları tercüme faaliyetlerine bağlamak yüksek bir ihtimaldir. İlgili öğretinin halka anlatılması çabasıyla verilmek istenen mesajı halka anlatma çabasını doğurarak birebir çeviri arzusuyla bu tip cümle yapılarının söz dizimsel olarak Eski Uygur Türkçesinde yoğun kullanıma sahip olmaları, aslında çok iyi bilinen bir durumdur. Marcel Erdal, konuyla ilgili olarak "Eski Uygur Türkçesi metinlerinin çoğu, çeviri niteliğindedir. Bu çevrilerden bir dereceye kadar gramatik etki beklenebilir. Özellikle çevirmenlerin asıl kaynakları en iyi şekilde aktarma çabası sadece bir sözcük düzeyinde değil biçimbirim ve cümle düzeyinde de aktarımı mümkün kılmaktadır. Eski Uygur Türkçesi metinleri bu doğrultuda dil ilişkileri yoluyla yabancı etkileri göstermektedir. Biz, doğrudan ödünç söz dizimi görünümlerini bu dönemde Hıristiyanlık dinine ait yazmalarda görmekteyiz. Şimdiye kadar hiçbir araştırmacı, bu konu üzerinde kapsamlı bir çalışma ortaya koyamamıştır. Bu metinlerin birkaç Asya dilinden gelmesi ve bazen farklı versiyonlarının olması, bu ilişkileri ele almayı zorlaştırmaktadır." (2004: 357, 358) açıklamasını yaparak Eski Uygur Türkçesine yönelik söz dizimi çalışmalarının zorluğundan yakınmaktadır. Eski Uygur Türkçesi dönemi söz diziminin genel özelliklerinden bahseden Serkan Şen, bu dönemin Türkçenin genel söz dizimi kurallarına uygunluk gösterdiğini belirterek Eski Uygur Türkçesinde yan cümlelerin Orhon Türkçesine göre yoğun bir kullanım içerisinde olduğunu ifade etmektedir. Şen, ayrıca Uygurca metinlerin çoğunun Soğdça, Toharca gibi Hint-Avrupa dillerinden çevrildiğini belirterek bu dillere ait cümle kuruluşunu orijinal bir şekilde yansıtmak amacıyla yan cümlelerin kullanımına değinmektedir (2014: 73). Eski Uygur Türkçesi dönemi cümle yapısından bahseden Eraslan, fiil unsurunun genellikle sonda yer aldığını, tercüme olan Uygur metinlerinde bu kurala uyulmadığını belirtmektedir (2012: 525). Görünüm açısından Hint Avrupa dillerine özgü yüklemin sonda değil de ortada olduğu bu durum, devrik tümce özelliği de taşımaktadır. Bu ifade özelinde dönemin sahip olduğu devrik cümle yapısını Altun Yaruk bağlamında ele alan Keskin, "Türk dilinin Eski Türkçe döneminde Orhon ve Uygur devrine ait cümlelerde devrik yapı, genellikle Türkçenin yabancı dillerle olan münasebeti ve Uygur devrindeki çoğu metinlerin tercüme olması ile açılanmıştır. Esasında, bugün hala Türkçede kullanılan devrik cümle yapısının nasıl ve ne şekilde oluştuğu, Türkçeye ait mi yoksa tamamen yabancı dillerin etkisiyle mi oluştuğu tam olarak açıllanamamaktadır." (2015: 41) ifadeleriyle Türk dilinde görülen devrik cümle yapılarının varlığını ve oluşum sebeplerini sorgulayarak bu görünümler üzerine net bir görüş beyan edememiştir.

Yabancı Etkili Cümle Dizilimi:

Türkçe Tarzı Cümle Dizilimi: ançulayu ärür/

Yüklem

mänin äșidmișim / $\underline{\text { mänin äșidmișim }}$

Özne

ançulayu ärür "Benim işittiğim şöyledir!"
“Şöyledir işittiğim!”

Eski Uygur Türkçesi dönemi ile özellikle Budizm temelli öğretilerin benimsenmesi sonucu, Türk diline yönelik çalışmaların bașlaması bilinen bir durumdur. Türk dilinin dinî terminolojisine yönelik çabaları, Budist Uygur rahiplerinin ortaya koydukları filolojik sistem ile görebiliriz. Bu filolojik çaba, Semih Tezcan (2001) tarafından ortaya konulan "En Eski Türk Dili ve Yazını" adlı çalışmada gösterilmiştir. Tezcan, eserinin "Eski Türk Çağında Filoloji ve Türkçecilik Çabaları" başlı̆̆ıla yer verdiği bölümünde Budizm ve Manihaizm gibi dinsel öğretilere ait kavramların Türkçeye aktarımında yaşanan zorluğa değinirken Budist Uygur rahiplerinin Türkçeleştirme amacıyla yoğun bir çaba harcadığını belirtmektedir. (2001: 315). 
Özne Yüklem

Eski Uygur Türkçesine ait metinlerde bir çeviri ürünü olarak tanıklanan ançulayu ärür mäniฤ äşidmişim ifadesi, söz dizimsel olarak ögelerine ayrıldığında, yüklemin sonda değil de, başta olduğu görülür. Türkçede yüklem çekirdeğinin sonda bulunması, sistematik sapmaları bulunan bir norm oluşturmaktadır. Özellikle günlük dilde bu sapmalar neticesinde yüklem çekirdeği, her zaman cümlenin sonunda bulunmaz. Ancak dilin kendi içerisinde bu tür varyantlarının bulunması, muhtemelen bir yabancı etkinin rolünü de düşündürtmektedir (Johanson 2007: 103). Buradaki yabancı etkiye karşllık gelen ifade, ödünçleme ya da kod kopyalama terimidir. Bu terimler, bir dilin başka bir dilden sesbirim, sözcük, biçimbirim ve söz dizim düzeylerinde ögeler alması demektir (İmer vd. 2019: 209). Bir dilin sistematik yapısı içerisinde değişime karşı en dayanıklı biriminin sözdizimi olduğu bilinen bir özelliktir. Thomason ve Kaufman'a göre yapısal unsurların kopyalanması için gereken temel ölçüt, iki dilli bir konuşur grubunun varlığıdır (1988: 66). Bahsi geçen araştırmacılarca dile getirilen iki dillilik durumunu, hem Budist hem de Manihaist Uygur rahipleri ile görmekteyiz. Uygur rahiplerinin kendi ana dillerinin yanında Çince, Soğdca, Toharca ve Sanskritçe gibi dilleri bilmeleri ve devamında bir dilde meydana gelen değişimin çeviri faaliyetlerinden de kaynaklanabileceği gerçeği göz önüne alındığında, yaşanan değişimin söz varlığı dışında gramer ve söz dizimine de yansıması, belirtilen iki dillikten kaynaklanan bir durumu sergilemektedir. Bu doğrultuda, Türkçe tipi cümle dizilimine sahip olmayan ançulayu ärür mänin äşidmişim ifadesinin Sanskritçe ve Çince gibi dillerdeki görünümüne bakıldığında, çeviri faaliyetleriyle Türkçe cümle dizilimi kuralında değişimin meydana geldiği anlaşılmaktadır.

\begin{tabular}{|c|c|}
\hline \multicolumn{2}{|c|}{ Uyg. ançulayu ärür mäniy äşidmişim } \\
\hline Skr. evaṃ mayā șrutam & Çin. 如是我聞 “rú shī wǒ wén”. \\
\hline evam = şöyle & $\begin{array}{c}\text { 如 rú=gibi, benzer. } \\
\text { 是 shi } \bar{i}=0 . \\
=\text { 如是 = böyle, şöyle, bunun gibi. }\end{array}$ \\
\hline maya $=$ ben & 我wǒ = ben \\
\hline srut-am = işitmek, duymak. & 聞wén= duymak, işitmek. \\
\hline
\end{tabular}

Tablo 1: Sanskritçe ve Çincede “Şöyle İşittim!” ifadesi

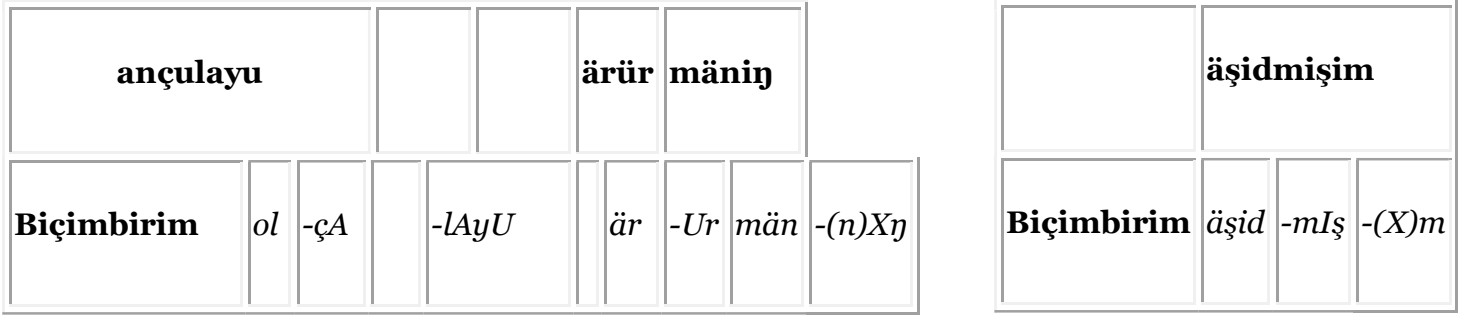

Tablo 2: Eski Uygur Türkçesinde ifadenin oluşumu http://vatec2.fkidg1.unifrankfurt.de/vatecasp/Altun_Yarok_Bo1.htm (Erişim Tarihi:18.03.2020).

Sanskritçe ve Çince gibi dillerde, "Şöyledir işittiğim" ya da "Şöyle işittim!" ifadesine karşılık gelen bu çeviriyi oluşturan birimlere bakıldığında, terimler arasında anlam ve söz dizimi ortaklığının her iki dilde de varlığı söz konusudur. Uygurcada da görülen bu anlam ve söz dizimi ortaklığı, bu ibarenin bir çeviri ürünü olduğunu göstermektedir. Eski Uygur Türkçesinde ançulayu ärür mäniฤ äşidmişim şeklinde yer alan bu terimin bir çeviri ürünü olarak yapısı incelendiğinde, ançulayu, ärür mäni ve äşidmişim şeklinde üç birimden meydana geldiği görülmektedir. Burada ançulayu ifadesi, Sanskritçe evam ve 
Çince rú shī; ärür mäni yapısı Sanskritçe mayā ve Çince wǒ ve son olarak da äşidmişim ifadesi, Sanskritçe șrut-am ve Çince wén ifadelerine karşllık gelmektedir. Oluşum yönü bakımından birebir çevirinin ürünü olan bu ifadenin tanıklandığı Eski Uygur Türkçesi metinlerine bakıldığında, bu eserlerin Tibetçe ya da Çince versiyonlara dayalı çeviri eser hüviyetinde oldukları görülmektedir. Bu doğrultuda, Eski Uygur Türkçesine ait metinlerde görülen bu ifade, oluşum yönü bakımından Budist Uygur rahiplerinin çeviri faaliyetleri neticesinde oluşturulmuş dinî bir kavram olma özelliğini taşımaktadır.

\section{Sonuç}

1. Türk dilinin dinî terminolojisinin özellikle Budizm temelinde sahip olduğu gelişkinlik, ançulayu ärür mänin äşidmişim ifadesiyle bir kez daha görülmüştür. Budist Uygur rahiplerinin başlattığı tercüme faaliyetleri ile ortaya çıkan filolojik çabayla işlenen Türk dili, çoğunlukla Orhon Türkçesindeki söylev nitelikli üslubunu Eski Uygur Türkçesi dönemi ile soyut ve metafizik bir seviyeye çıkarmıştır. Birebir çevirinin ürünü olarak Skr. evam mayā șrutam ifadesine karşılık türetilen ançulayu ärür mänin äşidmişim ifadesi, bu doğrultuda Türk dilinin soyut ve metafizik kavramları aktarmada da yetkinliğini gösteren somut bir dinî terim olma özelliğini taşımaktadır.

2. ançulayu ärür mäniฤ äşidmişim ifadesinin kaynak dildeki karşıllğı olan Skr. evam mayā șrutam teriminin Budizm içerisindeki değeri göz önüne alındığında, kavramın hem Mahāyāna hem de Mahāyāna mezhebi çerçevesinde gelişen Vajrayāna okulunda, Budist sūtralarla ilişkili olduğu, devamında giriş formeli olarak kullanılan bu terimin anlatılacak vaaz doğrultusunda sūtralara geçerlik katıp ilgili olaya tanıklık ettiği anlaşılmaktadır. Tarihsel Buda (Śakyamuni) ve müridi Ānanda'yı çağrıştıran bu ifade, Tantrik Budizm içerisinde Bhagavan'ın durumunu yoga açısından tanımlama amaçlı kullanımla sahiptir.

3. Skr. evaṃ mayā șrutam ifadesinin Eski Uygur Türkçesinde karşıllı bulduğu şekil olan ançulayu ärür mäniᄁ äşidmişim kavramı, Budist Uygur rahiplerince yapılan birebir çevirinin ürünü olarak ortaya konan dinî bir terimdir. Kaynak ya da aracı dilden etkilenilerek türetilen bu terim, çeviri yoluyla Türk dilinin söz dizimine yerleştirilen yabancı kaynaklı etkilerin örneği niteliğindedir.

\section{Kisaltmalar}

Çev. Çeviren.

Çin. Çince.

Ed. Editör.

İng. İngilizce.

Jap. Japonca.

Skr. Sanskritçe.

Uyg. $\quad$ Eski Uygur Türkçesi.

vd. ve diğerleri.

\section{Kaynakça}

Bang-Kaup, W., von Gabain, A. ve Arat, G. R. (1934). Das buddhistische Sūtra Säkiz Yükmäk. Türkische Turfan-Texte VI. Berlin: SPAW. 93-192.

Dibeltulo Concu, M.. (2017). Buddhism, Philosophy, History. On Eugène Burnouf's simple Sūtras. Journal of Indian Philosophy (45): 3. 473-511. 
Dictionary of Buddhism veritabanına https://www.nichirenlibrary.org/en/dic/Content/T/96\#para-o genel ağ sayfasından 18.03.2020 tarihinde erişildi.

Eraslan, K. (2012). Eski Uygur Türkçesi grameri. Ankara: Türk Dil Kurumu Yayınları.

Erdal, M. (2004). A grammar of Old Turkic . Leiden: Brill.

Farrow, G.W. ve Menon, I. (2001). The concealed essence of the Hevajra Tantra with the commentrary Yogaratnamala. Delhi: Motilal Banars Dass Publishers.

Harrison, P. (1979). The Pratyutpanna-Buddha-Sammukhāvastht Samādhi-Sūtra. An annotated English translation of the Tibetan version with several appendices. Doktora Tezi. Australian National University.

Harvey, P. (2013). An introduction to Buddhism: Teaching, history und practices. UK: Cambridge University Press.

Hartzell, J. F. (2012). The Buddhist Sanskrit Tantras: "The Samādhi of the plowed row". Journal of the Institute of Buddhist Studies, Third Series Number 14. 63-178.

İmer, K., Kocaman, A. ve Özsoy, A. S. (2019). Dilbilim sözlüğü. İstanbul: Boğaziçi Üniversitesi Yayınevi.

İsi, H. (2019). Eski Türkçe Tantrik bir metin: Ușnīssa Vijayā Dhāraṇī Sūtra. Doktora Tezi. Ankara: Hacettepe Üniversitesi Sosyal Bilimler Enstitüsü.

Jayadi, M. (2019). Early Mahāyāna Buddhism. The Journal of The International Buddhist Studies College. 26-50.

Johanson, L. (2013). Türkçe dil ilişkilerinde yapısal etkenler. Çev. Nurettin Demir. Ankara: Türk Dil Kurumu Yayınları.

Kaya, K. (2017). Buddhizm Sözlüğü. Ankara: Doğu Batı Yayınları.

Keown, D. (2003). A dictionary of Buddhism. UK: Oxford University Press.

Keskin, B. (2015) “Altun Yaruk Yedinci Kitap”tan hareketle Eski Uygur Türkçesinde devrik cümle yapısı. Istanbul Universitesi Edebiyat Fakültesi Türk Dili ve Edebiyatı Dergisi, 53 (2015-2). 39-52.

Khiewngamdee, S. (2017). The sitting posture and characteristic of Venerable Ānanda in Sukhāvatī vyūha Sūtra. Silpakorn University Journal of Social Sciences, Humanities, and Arts, Vol.17(3) : 71-84.

Kılıç Cengiz, A. (2018). Eski Uygur Türkçesi dönemine ait Tantrik bir metin: Sitātapatradhāraṇi. Doktora Tezi. Ankara: Hacettepe Üniversitesi Sosyal Bilimler Enstitüsü.

Kitsudo, K. (2017). Old Uighur version of the Sūtra of the causes and effects of actions. Studies On the Inner Asian Languages, XXXII. 33-49.

Kim, Y. (2003). An Intra-Buddhist dialogue between Theravāda and Mahāyāna: A hermeneutical search for common unity. International Journal of Buddhist Thought \& Culture, Vol. 3. 145-167.

Kozak, A. (2017). Buddhism 101: From Karma to the Four Noble Truths, your guide to understanding the principles of Buddhism. USA: Simon and Schuster.

McMahan, D. L. (2002). Empty Vision: Metaphor and Visionary imagery in Mahayana Buddhism. London: RoutledgeCurzon.

Miyamoto, S. (1959). Time and eternity in Buddhism. Journal of Bible and Religion, Vol. 27, No. 2. 118126.

O'Huiginn, D. (2005). Strategies of legitimation in Tantric Buddhism. Bitirme Tezi. UK: Cambridge University.

Osto, D. E. (2004). The Gandavyuha-sutra: A Study of wealth, gender and power in an Indian Buddhist narrative. Doktora Tezi. London: University of London.

Powers, J. (2007). Introduction to Tibetan Buddhism. USA: Snow Lion Publications.

Şen, S. (2014). Eski Uygur Türkçesi Dersleri. İstanbul: Bilge Kültür Sanat. 
Tezcan, S. (2001). En eski Türk Dili ve yazını. Bilim Kültür ve Öğretim Dili Olarak Türkçe içinde (s. 271323). Ankara: Türk Tarih Kurumu Basımevi.

Thomason, S. G. ve Kaufman, T. (1988). Language contact, creolization and Genetic Linguistics, Berkeley: University of California Press.

Tokyürek, H. (2013). Eski Uygurca dini terimlerde yabancı dillerin gramatikal etkisi var mıdır?. VIII. Milletlerarası Türkoloji Kongresi, 30 Eylül-4 Ekim 2013. 541-554.

Trungpa, C. (2004). The collected works of Chögyam Trungpa, Volume 6: Glimpses of space-orderly chaos-secret beyond thought-the Tibetan book of the dead: Commentary-Transcending Madness-selected writings. Ed. Carolyn Rose Gimian. Boston ve London: Shambhala Publications.

Vatec: Vorislamische Alttürkische Texte: Elektronisches Corpus veritabanına http://vatec2.fkidg1.unifrankfurt.de/vatecasp/Altun_Yarok_Bo1.htm genel ağ sayfasından 18.03.2020 tarihinde erişildi. 